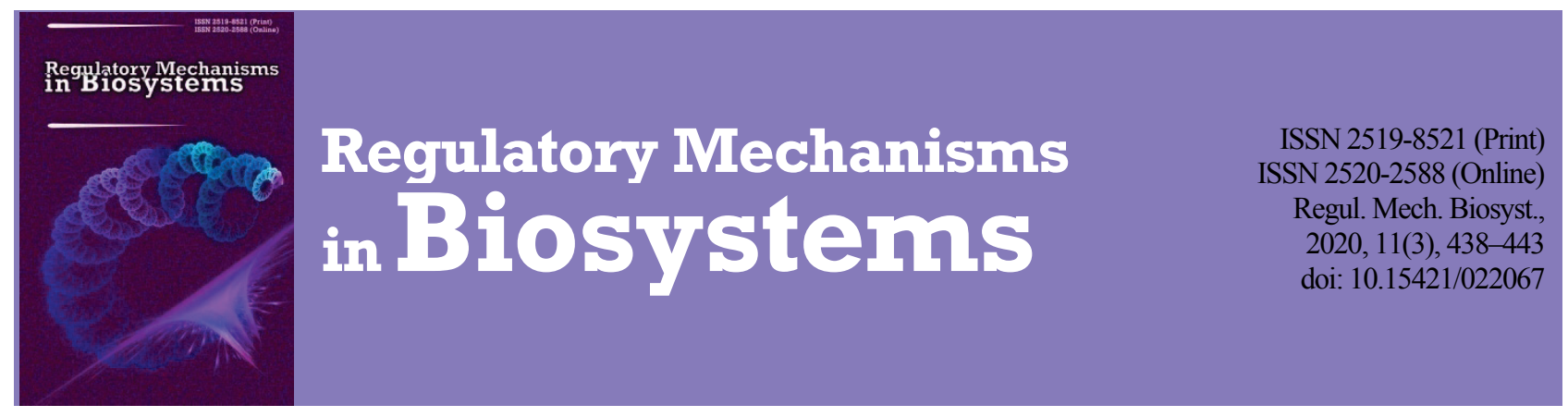

\title{
Dynamics of growing of Russian sturgeon (Acipenser gueldenstaedtii) larvae for different durations of cultivation
}

\author{
V. O. Kornienko, V. V. Olifirenko \\ Kherson State Agrarian University, Kherson, Ukraine
}

Article info

Received 15.06.2020 Received in revised form 20.07.2020

Accepted 21.07.2020

Kherson State Agrarian University, Stritenska st. 23, Kherson, 73006, Ukraine. Tel.: +38-099-953-30-41. E-mail:frank438@ukr.net

\begin{abstract}
Kornienko, V. O., \& Olifirenko, V. V. (2020). Dynamics of growing of Russian sturgeon (Acipenser gueldenstaedtii) larvae for different durations of cultivation. Regulatory Mechanisms in Biosystems, 11(3), 438-443. doi:10.15421/022067
\end{abstract}

In the context of the need to preserve the biodiversity of natural waters, the cultivation of valuable fish species for stocking natural reservoirs takes on exceptional importance. Optimization of the technology for growing sturgeon in artificial conditions has become the main goal of our research. The population used for the present study is from a fish farm, Dneprovskiy Sturgeon Fish Breeding Factory located in Belozersky district (Kherson region, Ukraine). Studies were conducted for ten years (2007-2017). The objective of our study is to assess the quality of juvenile sturgeon when grown with different durations. The research material was provided by the free embryos and larvae of Russian sturgeon (Acipenser gueldenstaedtii von Brandt \& Ratzeburg, 1833). Formation of experimental groups and calculation was performed on the principle of groups-analogues by standard methods. The main resultant criteria were larval survival, optimal extrinsic performance, and fish productivity. As a result of the conducted research it was determined that the optimal term of growing the larvae of $A$. gueldenstaedtii in the pools was 20 days. During this period, young sturgeon had high rates of average body weight with a survival rate of at least 53.4-60.2\% and optimal physiological state. In variants with a maximum growth period of 24 days, the difference in the individual masses of the test material was significantly increased on the background of rather high mass indices of the larvae (1.21.4 and 1.9-2.1 times, respectively for II-III variant). This led to an increase in the pressure of food competition and, as a result, to a decrease in the output of young sturgeon growth of up to 46.5-61.9\%. Survival of the larvae was by far the highest in the experimental groups with a minimum period of cultivation and ranged within $75.1-80.7 \%$. The maximum level of fish productivity was observed in the third variant of the experiment with the longest period of cultivation. An analysis of the relative indicators of body weight gain revealed that with the extension of the growing period in experimental variants the percentage of realization of growth of larvae during the period of exogenous feeding was proportionally reduced. The most effective use of feed for the growth of body weight of the larva was in the variant with a growing period of 20 days. Feed costs in these groups ranged within 2.80-3.24, which averaged 2.83-3.02. Analysis of the dynamics of oscillations of the main biochemical indicators showed that the accumulation of consumables in the body of the experimental larvae increased with the growing period of cultivation in the pools. The amount of moisture was adequately reduced. The greatest influence on the results of the growth of sturgeon larvae in the pools among all the considered factors belonged to the period of cultivation, the magnitude of significance of which was $61.2 \%$. The research results should significantly improve the technology of growing the Dnieper population of $A$. gueldenstaedtii on fish farms.

Keywords: average body weight; sturgeon cultivation; fish productivity; larval growth; biochemical parameters; fish fry.

\section{Introduction}

Recent decades have been characterized by an increase in technogenic and anthropogenic load on natural ecosystems, in particular those that exist mainly within the aquatic environment. The pressure of irrational fisheries and the polluting activities of humankind's production process have resulted in the redistribution of the qualitative and quantitative characteristics of the abiotic and biotic components of hydro-ecosystems (Tretjak et al., 2010; Sherman et al., 2013; Marenkov, 2018a, 2018b). This has led to both the extinction of some species and the decline in the number of others (Ambroz, 1956; Zalumy, 1970; Zalumy, 1973). In the past, the most valuable mass industrial species in the ichthyofauna of the Dnieper-Bug estuarine ecosystem were members of the sturgeon family. Until the 1960s in the ichthyofauna of Ukraine representatives of the sturgeon family included Beluga, Russian sturgeon, Northern sturgeon, Atlantic sturgeon and Thorn sturgeon, as well as the freshwater species - sterlet (Berg, 1949; Vladymyrov et al., 1963). By the mid-1990s, only the Russian sturgeon and the Northern sturgeon remained relatively numerous among the above-mentioned species (Sherman et al., 2009; Pilipenko et al., 2013; Sherman et al., 2018). In the Black Sea, up to $90.0 \%$ of sturgeon stocks are concentrated in its northwestern part, that is, largely directly on the Ukrainian coast (Movchan, 2011; Pilipenko et al., 2014). After a significant increase in catches in the 1950s, the number of Black Sea sturgeon decreased markedly. The situation has not changed much since the introduction of the ban on fishing. An increase in anthropogenic pressure in the early 21st century has led to all sturgeon species being entered in the Red Book of Ukraine (Akimov, 2009; Pilipenko et al., 2013). Thus, the current state of the Dnieper sturgeon populations remains critical and needs to be stepped up in efforts to restore the abundance and conservation of the biodiversity of the Dnieper-Bug estuarine ecosystem (Sherman et al., 2009; Grytsyniak et al., 2015). The same situation was observed with other populations of sturgeon (Ludwig et al., 2009; Ruban et al., 2019; Friedrich et al., 2019).

Conservation of the Dnieper sturgeon populations has always been a challenge for the fishery industry, which was primarily related to the biology of these fish (Ambroz, 1956; Tretjak et al., 2010, Grytsyniak et al., 2015). Sturgeon are fish with an extended life cycle. Late puberty and non-annual spawning determine their low reproductive ability. Against this background, the absence of the required number of spawning grounds makes it impossible to sustain the population of Dnieper sturgeon naturally (Sherman et al., 2009; Tretjak et al., 2010). At present, this is possible only under the conditions of artificial reproduction of sturgeon in fish factories 
and the introduction into natural water bodies of a considerable number of viable young of these species (Kolman et al., 2011; Vasileva et al., 2019). Studies have shown that the efficiency of works on artificial reproduction and growth of sturgeon for the fishing of natural water bodies depends to a large extent on the results of the growth of larvae. The latter is determined not only by the number of young sturgeon received and their qualitative characteristics, but also by the time required to reach the normative average mass of young sturgeon, which is the main criterion for transplanting material into growing ponds (Sherman et al., 2009; Chebanov et al., 2013; Vasileva, 2016).

This raised the need for specific research to address issues that need to be taken into account in technological processes in order to improve them. In this regard, the main goal of the work is to obtain data allowing the future quality of sturgeon fry to be predicted.

\section{Material and methods}

The research was guided by the principles of bioethics. The studies were carried out in accordance with the European Convention for the Protection of Vertebrate Animals used for Experimental and other Scientific Purposes ETS No. 123 and approved by the Science Council of the Kherson State Agrarian University. Research on a particular problem was initiated by us at the beginning of the century, and this publication is the result of the logical continuation of previous experimental work. The population used for the present study is from a fish farm, Dneprovskiy Sturgeon Fish Breeding Factory, located in Belozersky district (Kherson region, Ukraine). The research was conducted for ten years (2007-2017). During the design of the experiment, three variants of the experiment were formed with a gradation of the cultivation period: variant I - 16 days; variant II -20 days and variant III -24 days. The research material was composed of the free embryos and larvae of A. gueldenstaedtii. The formation of the study groups and the calculation was performed on the principle of groups of analogues by standard methods from females of one round of incubation (Ushkarenko et al., 2014; Pilienko et al., 2017). The study groups of each variant were harvested according to a series of experiments with a planting density of 2.8 and 3.2 thousand free embry$\mathrm{os} / \mathrm{m}^{2}$ and a triple repetition of variants. The average weight of free embryos during the formation of the experimental groups averaged $18.3 \pm$ $0.29 \mathrm{mg}(\mathrm{CV}=8.7 \%)$.

Control of the physical and chemical regime of the pools was carried out according to known recommendations (Alekin et al., 1973). Abiotic environmental factors were within the normative limits throughout the experiment. Average values of observations of water hardness and permanganate oxidation ranged from $3.9-5.0 \mathrm{mg} \mathrm{eq} / \mathrm{dm}^{3}$ and $11.8-25.2 \mathrm{mgO}_{2} / \mathrm{dm}^{3}$, chloride concentrations were within $39-51 \mathrm{mg} / \mathrm{dm}^{3}$, sulfates ranged from $32-57 \mathrm{mg} / \mathrm{dm}^{3}$. The water temperature of the experimental pools varied between $11.0-24.5^{\circ} \mathrm{C}$ during the observation period, which averaged about $17.3^{\circ} \mathrm{C}$ over the whole growing period. A characteristic feature of the observations was that in the initial period of cultivation low water temperature values close to the minimum regulatory values were observed. The oxygen content in the water of the experimental tanks in the first 16 days of cultivation ranged within $6.1-9.8 \mathrm{mg} \mathrm{O}_{2} / \mathrm{dm}^{3}$ and subsequently decreased to $5.6-5.9 \mathrm{mg} \mathrm{O}_{2} / \mathrm{dm}^{3}$. The hydrogen index of water of the pools fluctuated from 8.1-8.3. At the beginning of feeding of young experimental groups the water temperature fluctuated within $11.0-13.2^{\circ} \mathrm{C}$.

The analysis of larval growth was carried out once every 4 days. The minimum sample was at least 150 specimens of each variant. The main biochemical parameters were determined using conventional methods (Flerova, 2014), the volume of samples was not less than 100 specimens of each variant. The larvae of the study groups were fed with live feed (daphnia and oligochaetes) three times a day with a relative daily diet of $25.0-30.0 \%$ of the average body weight. The transition to external feeding was observed on days 11-12 of cultivation. The main resultant criteria received for the impact of the growing period on the quality of the young were the survival of the larvae, the achievement of optimal exterior indicators of the study material, fish productivity. The indicators were calculated by the direct accounting method (Ushkarenko et al., 2014). Data are presented as mean values and standard error ( $x \pm$ $\mathrm{SE}$ ). Statistical analysis was performed by means of analysis of variance (one-way ANOVA). A value of $\mathrm{P}<0.05$ was considered statistically significant. The differences between the values were determined using the Bonferroni correction. Analysis of variance of the influence of technological and environmental factors on the growth of larvae was carried out using the MANOVA test.

\section{Results}

The average mass of larvae in the experimental groups, depending on the duration of rearing, increased from $63 \mathrm{mg}$ in the first variant to $126 \mathrm{mg}$ in the groups, the rearing time of which was the maximum (Table 1).

\section{Table 1}

Influence of the duration of cultivation in the pools on the quality of larvae of $A$. gueldenstaedtii at a planting density of 2800 free embryos $/ \mathrm{m}^{2}(\mathrm{x} \pm \mathrm{SE})$

\begin{tabular}{cccccc}
\hline $\begin{array}{c}\text { Growing } \\
\text { time, day }\end{array}$ & $\begin{array}{c}\text { Pool } \\
\text { number }\end{array}$ & $\mathrm{n}$ & $\begin{array}{c}\text { Average body } \\
\text { weight, } \mathrm{mg}\end{array}$ & $\begin{array}{c}\text { Survival, } \\
\%\end{array}$ & $\begin{array}{c}\text { Fish productivity, } \\
\mathrm{g} / \mathrm{m}^{2}\end{array}$ \\
\hline \multirow{2}{*}{16} & 1 & 118 & $74.2 \pm 17.9$ & 76.6 & 120 \\
& 2 & 106 & $70.7 \pm 16.4$ & 84.8 & 125 \\
& 3 & 124 & $77.1 \pm 16.8$ & 75.2 & 162 \\
\hline \multirow{2}{*}{20} & 13 & 113 & $104.9 \pm 20.4$ & 73.1 & 177 \\
& 14 & 122 & $112.2 \pm 23.8$ & 70.6 & 186 \\
& 15 & 109 & $108.8 \pm 21.6$ & 66.3 & 168 \\
\hline \multirow{2}{*}{24} & 69 & 127 & $182.6 \pm 35.9$ & 54.9 & 253 \\
& 70 & 123 & $166.2 \pm 31.1$ & 61.3 & 254 \\
& 71 & 108 & $174.1 \pm 33.2$ & 52.4 & 229 \\
\hline
\end{tabular}

At the same time with the lengthening of the growing period, there was a significant increase in the variability of the individual mass of the larvae in the experimental groups. In the first variant of the experiment with a minimum period of cultivation, the coefficient of variation of this indicator was not very high and ranged within 16.4-18.3\%. Subsequently, the difference increased (1.2-1.4 and 1.9-2.1 times, respectively for variant II-III). The survival rate of larvae was by far the highest in the experimental groups with the minimum growing period and ranged within $75.1-80.7 \%$, which averages $78.4 \%$. When grown up to 20 days, the survival rate of the larvae was significantly reduced; the difference in yield from cultivation in comparison with the first option in individual pools reached $21.1 \%$ and averaged about $70.3 \%$. The survival rate of larvae during cultivation, which was obtained according to the third variant of the experiment, was the lowest. The survival rate of the test material in individual pools was relatively low, did not exceed $64.1 \%$ and averaged $61.9 \%$. The highest level of fish productivity was observed in the third variant of the experiment with the longest period of cultivation and averaged $186 \mathrm{~g} / \mathrm{m}^{2}$ with oscillations in individual basins within $166-188 \mathrm{~g} / \mathrm{m}^{2}$.

Dynamics of growth of body weight of experimental larvae reflected the features of growth in individual experimental groups. By the end of the growing period of 16 days, the growth rate of the larvae of all the experimental groups was practically the same; the difference in the growth rate did not exceed $2.0-5.1 \%$. The average water temperature in this period was $15.5^{\circ} \mathrm{C}$, which, in our opinion, mainly caused the low average mass of larvae, which did not reach the normative values and ranged within 62.9-65.0 $\mathrm{mg}$ in individual experimental groups. The increase in the growing time and the gradual increase in the water temperature to an average of $17.2^{\circ} \mathrm{C}$ caused an increase in body weight of an average of $30-32 \mathrm{mg}$, which allowed the test material to reach normative parameters of the average mass of 91-98 mg. The further increase of the growing period up to 24 days and the water temperature on the average to $18.3^{\circ} \mathrm{C}$ caused the increase of body weight on average by another $29-32 \mathrm{mg}$.

Against this background, in the experimental groups, the larvae of which were growing for a period of 24 days, in the last four days of cultivation there was a gradual decrease in the growth rate, which, in our opinion, reflected the deterioration of biotic relationships in the experimental larvae of this age group, which is characteristic of $A$. gueldenstaedtii aged 20-24 days in dense groups in general and for young Dnieper shoals in particular. An analysis of the relative indicators of body weight gain revealed that with the growth of the growing period in experimental variants the percentage of realization of growth of larvae during the period of exogenous feeding is proportionally reduced. With a 16-day growing period, the realization of growth before the transition of the experimental material 
to external feeding at the age of 12 days occupied a significant proportion and averaged $52.8 \%$.

With the increase of the growing period up to 20 and 24 days, the volume of realization of growth potential of Russian sturgeon larvae during the endogenous feeding period naturally decreased and fluctuated on average within 30.9 and $22.2 \%$ respectively. Against the background of an increase in the percentage of realization of the growth potential of the larvae during the feeding period with the increase in the period of growth and consumption of feed per unit of production, they gradually decreased. The most effective use of feed for the growth of body weight of the larvae was in the variant with a growing period of 20 days. Feed costs in these groups ranged within 2.80-2.86, which averaged 2.83. The highest feed costs were characteristic of the experimental groups which were reared with a minimum term of 16 days. The feed costs of the experimental material of this variant in individual variants ranged within 3.25-3.39, which averages 3.36 .

Regardless of the experimental group and the period of cultivation, the lowest rates of mass accumulation were observed at the beginning of cultivation and at the time of transfer of larvae to external feeding. Indicators of mass accumulation in these periods ranged from $0.11-0.12$ and $0.21-0.22$, respectively. After the transition of the larvae of the first variant to exogenous feeding, the indices of mass accumulation increased sharply and reached $0.32-0.36$. With the extension of the growing period to 20 days, the rate of increase of the mass accumulation coefficient, although slightly decreased, reached maximum values in the limits of 0.41 0.43 . In the future, with the increase of the growing period up to 24 days, the indices of mass accumulation decreased to $0.31-0.32$.

Taking into account the modern requirements on the criteria for determining the quality of grown sturgeon, we determined the variability of certain biochemical parameters of larvae when kept in the pools using different cultivation terms. The difference in growing time is significantly reflected in the magnitude of the overall biochemical parameters. Analysis of the dynamics of oscillations of the main biochemical indicators showed that the accumulation of consumables in the body of the experimental larvae increased with the growing period of cultivation in the pools. The amount of moisture was adequately reduced. The highest moisture values of $90.2 \%$ were observed in the first variant of the experiment with the lowest ash, fat and protein content, which was $1.1 \%, 3.2 \%$ and $5.5 \%$ respectively (Table 2). In the experimental groups of the third variant with a 24 day period of growing in pools, the content of consumables in the body of the experimental larvae was the highest, the amount of ash was $1.3 \%$, fat $-3.9 \%$, protein $-5.9 \%$.

\section{Table 2}

Influence of the term of cultivation of sturgeon larvae at 2800 free embryos $/ \mathrm{m}^{2}$ on biochemical parameters (in $\%$ of raw material; $\mathrm{x} \pm \mathrm{SE}, \mathrm{n}=468$ )

\begin{tabular}{ccccc}
\hline Growing time, day & Moisture & Ash & Fat & Protein \\
\hline 16 & $90.2 \pm 4.20$ & $1.10 \pm 0.32$ & $3.20 \pm 0.61$ & $5.52 \pm 1.01$ \\
20 & $89.5 \pm 3.69$ & $1.21 \pm 0.21$ & $3.58 \pm 1.33$ & $5.71 \pm 2.43$ \\
24 & $88.9 \pm 3.06$ & $1.32 \pm 0.41$ & $3.91 \pm 0.89$ & $5.89 \pm 1.34$ \\
\hline
\end{tabular}

Note: there were no statistical differences $(\mathrm{P}<0.05)$ according to the Bonferroni correction.

In the second series of the experiment, in which the density of the experimental groups in the fishery was taken within 3200 free embryos $/ \mathrm{m}^{2}$, a pattern similar to the previous analysis is observed. As in the previous series of experiments, the average mass of larvae in the experimental groups, depending on the duration of cultivation increased steadily from $59 \mathrm{mg}$ with oscillations in individual groups within 57.39-63.96 in the first embodiment to $119 \mathrm{mg}$ with oscillations in individual groups in the range of 114-126 $\mathrm{mg}$ in the groups with the maximum growing time (Table 3). Survival of the larvae was the highest in the experimental groups with the minimum period of cultivation and ranged within 72.6$78.5 \%$, which on average was $76.1 \%$. The lowest survival rates of sturgeon larvae for rearing were obtained naturally in the third variant of the experiment; the survival rate in some pools was very low, did not exceed $55.1 \%$ and averaged $54.4 \%$. The fish productivity of the experimental groups gradually increased with the increase of the growing period and the growth of the average mass of the larvae. The minimum indicators of fish productivity are characteristic of the experimental groups according to the first variant of the experiment with a growing period of 16 days, on average $101.41 \mathrm{~g} / \mathrm{m}^{2}$ with fluctuations in individual basins within the range of 96-106 g/ $\mathrm{m}^{2}$. The maximum level of fishery productivity was observed in the third variant of the experiment with the largest period of cultivation and averaged $175 \mathrm{~g} / \mathrm{m}^{2}$ with oscillations in individual basins within 169 $183 \mathrm{~g} / \mathrm{m}^{2}$. As in the previous series of experiments, by the end of the 16day period, the growth rate of the larvae of all experimental groups was naturally practically the same; the difference in growth rate did not exceed $3.0-5.0 \%$. The growth rate of body weight was low and the larvae did not reach regulatory values. The average mass of the larvae ranged within 59 $63 \mathrm{mg}$ in individual study groups. The increase in the period of growth and the gradual increase in the temperature of the water caused the body weight to increase by an average of $27-28 \mathrm{mg}$, which allowed the test material to reach normative parameters of the average mass of 84-92 mg. Further increase of the growing period to 24 days and the water temperature on the average to $18.25^{\circ} \mathrm{C}$ caused the increase of body weight in comparison with the minimum growing period by an average of $30-34 \mathrm{mg}$.

\section{Table 3}

Influence of the term of cultivation in the pools on the quality of larvae of $A$. gueldenstaedtii at a planting density of 3200 free embryos $/ \mathrm{m}^{2}(\mathrm{x} \pm \mathrm{SE})$

\begin{tabular}{cccccc}
\hline $\begin{array}{c}\text { Growing } \\
\text { time, day }\end{array}$ & $\begin{array}{c}\text { Pool } \\
\text { number }\end{array}$ & $\mathrm{n}$ & $\begin{array}{c}\text { Average body } \\
\text { weight, } \mathrm{mg}\end{array}$ & $\begin{array}{c}\text { Survival, } \\
\%\end{array}$ & $\begin{array}{c}\text { Fish productivity, } \\
\mathrm{g} / \mathrm{m}^{2}\end{array}$ \\
\hline \multirow{2}{*}{16} & 5 & 117 & $71.5 \pm 18.2$ & 76.7 & 131 \\
& 6 & 111 & $71.7 \pm 18.7$ & 79.3 & 136 \\
& 7 & 109 & $69.3 \pm 17.4$ & 80.5 & 132 \\
\hline \multirow{2}{*}{20} & 77 & 110 & $107.1 \pm 27.8$ & 65.6 & 163 \\
& 78 & 128 & $96.2 \pm 26.1$ & 68.1 & 169 \\
& 79 & 121 & $101.8 \pm 27.6$ & 67.5 & 180 \\
\hline \multirow{3}{*}{24} & 65 & 105 & $146.8 \pm 35.4$ & 57.2 & 235 \\
& 66 & 114 & $157.3 \pm 37.9$ & 51.2 & 228 \\
& 67 & 109 & $154.3 \pm 36.5$ & 50.9 & 222 \\
\hline
\end{tabular}

An analysis of the relative indicators of body weight gain, as in the previous series of experiments, revealed that with the increase of the growing period in experimental variants the percentage of realization of growth of larvae during the endogenous feeding period was proportionally reduced. During the growing period of 16 days, the realization of growth before the transition of the test material to external feeding at the age of 12 days occupied a significant share and averaged 57.1\%.With the extension of the growing period to 20 and 24 days, the volume of growth of larvae during the endogenous feeding period naturally decreased and fluctuated on average within $34.4 \%$ and $23.3 \%$.

As in the previous series of experiments, with the increase in the growing period feed costs per unit of production gradually decreased. The most effective use of forage for growth of body weight of larvae of experimental groups was in the variant with the term of cultivation of 20 days. Feed costs in these groups are slightly higher than those in the less dense groups and range within $2.96-3.24$, which are 3.02 on average. The highest feed costs are characteristic of the experimental groups which are reared with a minimum term of 16 days. The feed costs of the experimental material of this variant for individual experimental groups ranged within 3.61-4.15, which averaged 3.89.

However, the overall dynamics of oscillation coefficient of mass accumulation in comparison with the previous series remained virtually unchanged. The minimum indices of mass accumulation were observed at the beginning of cultivation and at the time of larvae transition to external feeding $-0.11-0.12$ and $0.21-0.23$, respectively. Subsequently, a significant increase in the values of mass accumulation was observed, which reached $0.40-0.41$ by 20 days of cultivation.

Analysis of the dynamics of oscillations of the main biochemical parameters showed that, as in the previous series of experiments with increasing duration of cultivation, the amount of moisture was adequately reduced. The highest moisture values of $90.6 \%$ were observed in the first version of the experiment with the lowest ash, fat and protein content, which was $1.1 \%, 3.2 \%$ and $5.1 \%$ respectively (Table 4 ). In the experimental groups of the third variant with a 24 day period of larvae growing in the pools, the content of consumables in the body of the experimental larvae was the highest, the amount of ash was $1.3 \%$, fat $-3.6 \%$, protein $-5.7 \%$. 
Table 4

Influence of the duration of cultivation of sturgeon larvae at 3200 free embryos $/ \mathrm{m}^{2}$ on biochemical parameters (in $\%$ of raw material; $x \pm S E, n=473$ )

\begin{tabular}{ccccc}
\hline Growing time, day & Moisture & Ash & Fat & Protein \\
\hline 16 & $90.6 \pm 4.19$ & $1.10 \pm 0.61$ & $3.2 \pm 2.13$ & $5.1 \pm 0.56$ \\
20 & $90.0 \pm 5.43$ & $1.21 \pm 2.13$ & $3.2 \pm 1.72$ & $5.6 \pm 2.30$ \\
24 & $89.4 \pm 3.11$ & $1.32 \pm 1.89$ & $3.6 \pm 1.14$ & $5.7 \pm 1.12$ \\
\hline
\end{tabular}

Note: there were no statistical differences $(\mathrm{P}<0.05)$ according to the Bonferroni correction.

The mathematical analysis showed a high level of correlation between the period of sturgeon cultivation in the basins and the main fishery indicators, regardless of the thermal regime of individual years of observation, correlation coefficients ranged $0.812-0.975$. The obtained pairs of dependencies allowed us to determine the maximum relationship between the analyzed indicators, which allowed us to build mathematical models of the relationship between the term of growth of Russian sturgeon larvae in the pools and the rate of their growth. The best dependence of body mass growth on planting density is described by exponential equations, favouring high levels of approximation within 0.988-0.997 (Table 5). In the course of further mathematical analysis, the magnitude of the impact on the main fishery indices of the rearing period as the main factor and the density of the groups at a certain water temperature in the pools was determined (Table 6).

\section{Table 5}

Dependences of growth of body weight

of larvae of $A$. gueldenstaedtii on the term of cultivation in pools ( $\mathrm{y}$ - the mass of larvae, $\mathrm{g} ; \mathrm{x}$ - growing duration, days)

\begin{tabular}{cccc}
\hline \multirow{2}{*}{$\begin{array}{c}\text { Free } \\
\text { embryos } / \mathrm{m}^{2}\end{array}$} & Growing & \multicolumn{2}{c}{ Indicators of dependence } \\
\cline { 3 - 4 } 2800 & 16 & $\mathrm{y}=12.289 \mathrm{e}^{0,3195 \mathrm{x}}$ & coefficient of approximation, $\mathrm{R}^{2}$ \\
\hline \multirow{2}{*}{20} & $\mathrm{y}=11.752 \mathrm{e}^{0,3329 \mathrm{x}}$ & 0.9783 \\
& 24 & $\mathrm{y}=11.763 \mathrm{e}^{0,3382 \mathrm{x}}$ & 0.9854 \\
& 24 & 0.9906 \\
\hline \multirow{3}{*}{3200} & 16 & $\mathrm{y}=12.584 \mathrm{e}^{0,3066 \mathrm{x}}$ & 0.9882 \\
& 20 & $\mathrm{y}=12.211 \mathrm{e}^{0,3206 \mathrm{x}}$ & 0.9886 \\
& 24 & $\mathrm{y}=11.923 \mathrm{e}^{0,3282 \mathrm{x}}$ & 0.9917 \\
\hline
\end{tabular}

Table 6

The results of variance analysis of the influence of technological and environmental factors in the growth of larvae of $A$. gueldenstaedtii

\begin{tabular}{|c|c|c|c|c|c|c|}
\hline \multirow{2}{*}{ Source of variation } & \multirow{2}{*}{$\begin{array}{c}\text { Sum } \\
\text { of squares }\end{array}$} & \multirow{2}{*}{$\begin{array}{l}\text { Degrees of } \\
\text { freedom }\end{array}$} & \multirow{2}{*}{$\begin{array}{l}\text { The middle } \\
\text { square }\end{array}$} & \multicolumn{2}{|c|}{$\mathrm{F}$} & \multirow{2}{*}{$\begin{array}{l}\text { The volume of mutual } \\
\text { influence of factors, } \%\end{array}$} \\
\hline & & & & actually & theoretically & \\
\hline General & 1036589.1 & 161 & - & - & - & \\
\hline Repeats & 111.3 & 2 & - & - & - & \\
\hline Factor A - planting density, free embryos $/ \mathrm{m}^{2}$ & 2400.1 & 2 & 1200.1 & 123.2 & 6.94 & $0.2^{*}$ \\
\hline Factor $\mathrm{B}$ - water temperature, ${ }^{\circ} \mathrm{C}$ & 40714.6 & 5 & 8142.9 & 138.4 & 2.97 & $2.9^{*}$ \\
\hline Factor $\mathrm{C}$ - growing time, days & 865201.7 & 2 & 432600.8 & 15995.4 & 3.12 & $61.2^{* * *}$ \\
\hline Interactions $\mathrm{AB}$ & 13040.6 & 10 & 1304.1 & 22.1 & 2.60 & $0.9^{*}$ \\
\hline Interactions $\mathrm{AC}$ & 188044.1 & 4 & 47011.0 & 1738.2 & 2.49 & $13.3^{* *}$ \\
\hline Interactions BC & 81429.3 & 10 & 8142.9 & 301.0 & 1.96 & $5.8^{* *}$ \\
\hline Interactions $\mathrm{ABC}$ & 218925.7 & 20 & 10946.2 & 404.7 & 1.72 & $15.5^{* *}$ \\
\hline
\end{tabular}

Note: $*$ - low level of influence factor; $* *$ - average level of influence factor; $* * *$ - high level of influence factor.

The greatest influence on the results of the growth of sturgeon larvae in the pools among all the considered factors belonged to the period of cultivation, the magnitude of significance of which is $61.2 \%$. At the same time, in this series of experiments, abiotic and biotic factors of the environment influenced the cultivation results much less, the value of significance at water temperature is $2.9 \%$, and for planting density - only $0.2 \%$. All three factors combined are significant, with $15.5 \%$ interaction. Against this background, the calculated Fisher's criterion for all factors of the studied effects is higher than the theoretical one, which indicated the reliability of the data obtained.

\section{Discussion}

Sturgeons are considered to be one of the most globally imperiled taxa, most of the species are listed by the International Union for the Conservation of Nature (Haxton, 2016). The analysis of the factors that influence the productivity of the Dnieper sturgeon populations, allows us to formulate the basic provisions of the concept of the directed formation of the industrial ichthyofauna of the Dnieper-Bug estuary. According to the literature data, the rational use of natural waters should be based, first of all, on the conservation of the biodiversity of the fauna, which includes efforts to restore the number of rare and endangered fish species (Tretjak et al., 2010; Sherman et al., 2013; Hliebova \& Shkarupa, 2019). At the same time, modern trends in fisheries development require an increase in the volume of hydrobiota production from both natural and artificial waters. In the case of sturgeon, the basic measures for the protection and amelioration of the foraging and spawning grounds will not allow the Dnieper shoals to be restored. The latter in the present is possible solely due to the introduction of the required amount of high-quality viable planting material in natural waters (Chebanov et al., 2013; Sherman et al., 2013). At the same time, one of the main issues on which the scale and success of sturgeon based on natural and artificial water bodies depends is the provision of effective artificial reproduction and cultivation of viable fishery material at sturgeon fisheries (Sherman et al., 2009; Gritsinyak et al., 2016). In this regard, the study of the impact of environmental and technological parameters on the efficiency of larval growth to viable stages is crucial.

It is known that the effectiveness of the introduction of young sturgeon into natural water bodies largely depends on their size and mass indicators (Sherman et al., 2009; Pilipenko et al., 2014). Previous research has determined that the efficiency of obtaining young sturgeon of different mass under any temperature conditions depends very much on the period of cultivation in the pools (Sherman et al., 2009; Chebanov et al., 2013). With optimal growing times, larvae of Russian sturgeon reach the required growth parameters and have a high survival rate. Their mass, length, biochemical parameters are sufficient for transplanting for cultivation in ponds (Sherman et al., 2009; Chebanov et al., 2013; Vasileva et al., 2016). In our opinion, low values of water temperature in the initial growing season and the short growing period can be the probable cause of the worst results of the experiment. In the first variant of the experiment with a rearing duration of 16 days, the larvae of the $A$. gueldenstaedtii of all groups did not reach the standard average body weight. Growing the larvae of Russian sturgeon in the shortest time is possible only with a high biomass of food organisms in ponds, which is not typical for classical ponds for growing sturgeon. The expediency of growing larvae within the time frame determined by us is confirmed in other research (Chebanov et al., 2013; Simon, 2018). Analysis showed that this is also typical for other sturgeon species (Tretjak et al., 2020). It was also found that in variants with the maximum growing time, the difference in the individual masses of the test material was greatly increased on the background of sufficiently high fishery indicators. This has led to an increase in the pressure of food competition and, as a result, to a decrease in the output of young sturgeon growing up. At the same time, it was shown that with an increase in the growing period, moisture in sturgeon muscles decreases and fat and protein increase (Poleksic et al., 2010; Memis et al., 2011; Kairullaev et al., 2017; Lee et al., 2017). Corresponding age-related changes have been studied in other fish species (Volichenko et al., 2017; Payuta \& Flerova, 2020). Timely completion of the process of rearing juveniles in pools will reduce the death of larvae of Russian sturgeon (Sherman et al., 2009; Chebanov et al., 2013). But if it is necessary to obtain larger 
planting material of young Dnieper sturgeon, the growing period can be extended during cultivation, though it will be necessary to sort out the young in the last week of cultivation.

\section{Conclusion}

As a result of the conducted research it is determined that a 20 day term of growing the larvae of $A$. gueldenstaedtii in the pools should be considered the most optimal. During this period, larvae of $A$. gueldenstaedtii had high rates of average body weight of $83-108 \mathrm{mg}$ with a survival rate of at least $53.4-60.2 \%$ and optimal physiological state. With the shortening of the rearing time, the larvae did not reach the required technological and biological parameters. In variants with a maximum growth period of 24 days, the difference in the individual masses of the test material significantly increased on the background of rather high fishery indicators of the larvae, the coefficient of variation of the index reached $50.3-52.9 \%$. This led to an increase in the pressure of food competition and, as a result, to a decrease in the output of sturgeon fry from growing to $46.5-61.9 \%$. All of this can have a significant impact on the development of new technologies for growing sturgeon.

\section{References}

Akimov, I. A. (2009). Chervona knyha Ukrainy. Tvarynnyi svit [Red Book of Ukraine. Fauna]. Hlobalkonsaltynh, Kyiv (in Ukrainian).

Alekin, O. A., Semenov, A. D., \& Skopintsev, B. A. (1973). Rukovodstvo po himicheskomu analizu vod sushi [Guide to the chemical analysis of land water]. Hydrometyzdat, Leningrad (in Russian).

Alkhimov, E. M., \& Shevchenko, V. Y. (2017). Suchasnyi stan vyroshchuvannia remontnykh tsoholitok osetropodibnykh ryb (Acipenseriformes) v umovakh Pivdnia Ukrainy [Current state of the rearing of replacement young-of-the-year (Acipenseriformes) in the conditions of the southern Ukraine]. Rybohospodarska Nauka Ukrainy, 39, 52-63 (in Ukrainian).

Ambroz, A. Y. (1956). Ryby Dnepra, Yuzhnogo Buga i Dneprovsko-Bugskogo limana [Fish of the Dnieper, Southern Bug and Dnieper-Bug Estuary]. Izdatelstvo AN URSR, Kyiv (in Russian).

Berg, L. S. (1949). Ryby presnyh vod SSSR i sopredelnyh stran [Freshwater fish of the USSR and neighboring countries]. Izdatelstvo Akademii Nauk SSSR, Moscow, Leningrad (in Russian).

Chebanov, M. S., \& Galich, E. V. (2013). Sturgeon hatchery manual. Food and Agriculture Organization of the United Nations, Ankara.

Flerova, E. A. (2014). Fiziologo-biohimicheskie metody issledovaniya ryb [Physiological and biochemical methods for the study of fish]. Izdatelstvo of Yaroslavl' State Agricultural Academy, Yaroslavl' (in Russian).

Friedrich, T., Reinart, R., \& Gessner, J. (2019). Sturgeon re-introduction in the Upper and Middle Danube River Basin. Journal of Applied Ichthyology, 35, 1059-1068.

Grytsyniak, I. I., Sharko, D. P., Shkarban, V. V., \& Plichko, V. F. (2015). Current state and development of the fisheries sector of Ukraine in the crisis. Rybohospodarska Nauka Ukrainy, 31, 5-15.

Haxton, T. J., \& Cano, T. M. (2016). A global perspective of fragmentation on a declining taxon - the sturgeon (Acipenseriformes). Endangered Species Research, 31, 203-210.

Heina, K. M. (2019). Stan ta dynamika popovnennia promyslovoho zapasu ikhtiofauny ponyzziv r. Dnipro [State and dynamics of replenishment of the industrial stock of ichthyofauna of the lower reaches of the Dnieper River]. Rybohospodarska Nauka Ukrainy, 47, 17-27 (in Ukrainian).

Hliebova, Y. A., \& Shkarupa, O. V. (2019). Dynamika rozvytku rybnoho hospodarstva Ukrainy u 2016-2018 rokakh [Dynamics of fisheries development in Ukraine in 2016-2018]. Rybohospodarska Nauka Ukrainy, 48, 520 (in Ukrainian).

Kairullaev, K., Kulmanova, G., Nurgazy, B., Nurgazy, K., \& Turganbayeva, F. (2017). Biological features of sturgeon in breeding process in pond fish farms of Almaty region. Ekoloji, 99, 1-8.

Lee, S., Sonmez, O., Hung, S., \& Fadel, J. (2017). Development of growth rate, body lipid, moisture, and energy models for white sturgeon (Acipenser transmonta$m u s$ ) fed at various feeding rates. Animal Nutrition, 3, 46-60.

Ludwig, A., Lippold, S., Debus, L., \& Reinartz, R. (2009). First evidence of hybridization between endangered sterlets (Acipenser rutherus) and exotic Siberian sturgeons (Acipenser baerii) in the Danube River. Biological Invasions, 11, 753-760.

Marenkov, O. M. (2018a). Ichthyofauna of the Zaporizhia Nuclear Power Plant cooling pond (Enerhodar, Ukraine) and its biomeliorative significance. Ukrainian Journal of Ecology, 8(2), 140-148.
Marenkov, O. N. (2018b). Ecological and biological aspects of zander and Volga zander reproduction under conditions of the Zaporizhzhia reservoir (Ukraine). Ukrainian Journal of Ecology, 8(1), 441-450.

Memis, D., Ercan, E., \& Yamaner, G. (2011). The effects of shaded pond on growth performance of Russian sturgeon (Acipenser gueldenstaedtii). Journal of Applied Ichthyology, 27, 571-575.

Movchan, Y. V. (2011). Ryby Ukrajiny (vyznachnyk-dovidnyk) [Fish of Ukraine (determinant-reference)]. Zoloti Vorota, Kyiv (in Ukrainian).

Payuta, A. A., \& Flerova, E. A. (2020). Dynamics of indices of metabolism in muscle tissue, liver and gonads of Abramis brama in different periods of the annual cycle. Biosystems Diversity, 28(2), 146-153.

Pilipenko, Y. V., Komienko, V. A., Plugatarev, V. A., \& Moshniahul, K. I. (2014). Itogi rabot po vosstanovleniyu chislennosti dneprovskikh osetrovykh [Results of the work on the restoration of sturgeon population in the Dnieper]. Voprosy Rybnogo Hozyajstva Belarusi, 30, 180-187 (in Russian).

Pilipenko, Y. V., Olifirenko, V. V., Kornienko, V. O., Polishuk, V. S., Dovbish, O. E., \& Lobanov, I. A. (2013). Ekologichni peredumovy racional'nogo vedennya rybnogo gospodarstva Dniprovs'ko-Buz'koyi gyrlovoyi oblasti [Ecological prerequisites for the rational management of fisheries in the Dnieper-Bug estuary region]. Vydavets Grin D. S., Kherson (in Ukrainian).

Pilipenko, Y. V., Shevchenko, P. G., Cedik, V. V., \& Kornienko, V. O. (2017). Metody ihtiologichnyh doslidzhen' [Methods of ichthyological research]. OldiPlus, Kherson (in Ukrainian).

Poleksic, V., Lenhardt, M., Jarić, I., Djordjevic, D., Gačić, Z., Cvijanovic, G., \& Raskovic, B. (2010). Liver, gills, and skin histopathology and heavy metal content of the Danube sterlet (Acipenser ruthenus Linnaeus, 1758). Environmental Toxicology and Chemistry, 29, 515-521.

Ruban, G., Khodorevskaya, R., \& Shantunovskii, M. (2019). Factors influencing the natural reproduction decline in the beluga (Huso huso, Linnaeus, 1758), Russian sturgeon (Acipenser gueldenstaedtii, Brandt \& Ratzeburg, 1833), and stellate sturgeon (A. stellatus, Pallas, 1771) of the Volga-Caspian basin: A review. Journal of Applied Ichthyology, 35, 387-395.

Sherman, I. M., Heina, K. M., Kutishchev, S. V., \& Kutishchev, P. S. (2013). Ekolohichni transformatsiji richkovykh hidroekosystem ta aktualni problemy rybnoho hospodarstva [Ecological transformations of riverine hydroecosystems and current problems of fisheries]. Rybohospodarska Nauka Ukrainy, 26, 5-16 (in Ukrainian).

Sherman, I. M., Kozii, M. V., Kornienko, V. O., \& Shevchenko, V. Y. (2018). Osetrivnytstvo [Sturgeon farming]. Oldi-Plus, Kherson (in Ukrainian).

Sherman, I. M., Shevchenko, V. Y., Kornienko, V. O., \& Ignatov, O. V. (2009). Ekoloho-tekhnolohichni osnovy vidtvorennia i vyroshchuvannia molodi osetropodibnykh [Ecological-technological bases of reproduction and cultivation of young sturgeon]. Oldi-Plus, Kherson (in Ukrainian).

Sydorov, M. A., Nevesela, O. O., Sazanova, N. M., \& Bezkrovna, N. I. (2009). Vplyv biolohichno aktyvnoi dobavky "torfovit" na biokhimichni pokaznyky tkanyn riznykh vydiv ryb [Influence of biologically active supplement "torfovit" on biochemical of tissues of different types of fishes]. Rybohospodarska Nauka Ukrainy, 9, 91-95 (in Ukrainian).

Symon, M. Y., Zabytivskyi, Y. M., \& Grytsyniak, I. I. (2018). Vplyv inaktyvovanykh pekarskykh drizhdzhiv na potentsial rostu molodi rosiis'koho osetra Acipenser gueldenstaedtii (Brandt) [Influence of inactivated baker's yeast on growth potential of russian turgeon Acipenser gueldenstaedtii (Brandt) fingerling]. Rybohospodarska Nauka Ukrainy, 45, 103-111 (in Ukrainian).

Tretjak, O. M., Hankevych, B. O., Kolos, O. M., \& Yakovlieva, T. V. (2010). Stan zapasiv osetrovyh ryb ta rozvytok osetrovoi akvakultury v Ukraini [To the questions on the state of sturgeons stocks and development of sturgeon aquaculture in Ukraine]. Rybohospodarska Nauka Ukrainy, 14, 4-22 (in Ukrainian).

Tretjak, O. M., Pashko, M. M., \& Kolos, O. M. (2020). Vyroshchuvannia lychynok sterliadi (Acipenser ruthenus Linnaeus, 1758) u netradytsiini stroky [Rearing sterlet (Acipenser ruthenus Linnaeus, 1758) larvae in non-traditional periods]. Rybohospodarska Nauka Ukrainy, 52, 29-37 (in Ukrainian).

Ushkarenko, V. O., Holoborodko, S. P., \& Kokovikhin, S. V. (2014). Metodyka polovoho doslidu (zroshuvalne zemlerobstvo) [Field experiment technique (irrigated agriculture)]. Grin D. S., Kherson (in Ukrainian).

Vasileva, L., Pilipenko, Y., Kornienko, V., Shevchenko, V., Kolman, R., \& Plugatarov, V. (2016). Akvakul'tura osetroobraznyh [Sturgeon aquaculture]. Grin D. S., Kherson (in Russian)

Vasilyeva, L. M., Elhetawy, A. I., Sudakova, N. V., \& Astafyeva, S. S. (2019). History, current status, and prospects of sturgeon aquaculture. Aquaculture Research, 50,979-993.

Vladimirov, V. Y., Sukhoivan, P. H., \& Buhai, K. S. (1963). Razmnozhenie ryb v usloviyah zaregulirovannogo stoka reki (na primere Dnepra) [Reproduction of fish in a regulated river flow (on the example of the Dnieper)]. Izdatelstvo AN SSSR, Kyiv (in Russian).

Volichenko, Y. M., Pentyliuk, S. I., \& Sherman, I. M. (2017). Sezonni zminy morfofiziolohichnoho stanu koropovykh ryb, vyroshchenykh za pasovyshchnoi tekhnolohii v umovakh Pivdnia Ukrajiny [Seasonal changes in the morphophysio- 
logical state of carp fish raised by grazing technology in the South of Ukraine] Rybohospodarska Nauka Ukrainy, 39, 84 -91 (in Ukrainian).

Zalumy, S. H. (1970). Sovremennyj sostav i nekotorye zakonomernosti formirovaniya ihtiofauny nizov'ev Dnepra v usloviyah zaregulirovaniya i sokrasheniya rechnogo stoka [The modern composition and some patterns of the formation of the ichthyofauna of the lower reaches of the Dnieper in conditions of regulation and reduction of river flow]. Voprosy Ihtiologii, 10(5), 779-789 (in Russian).

Zalumy, S. H. (1973). Izmeneniya v rybnom promysle v nizovyah Dnepra, Yuzhnogo Buga i Dneprovsko-Bugskogo limana posle zaregulirovaniya [Changes in fishery in the lower reaches of the Dnieper, Southern Bug and Dnieper-Bug estuary]. Rybnoe Hozyajstvo, 17, 81-87 (in Russian). 